BACKGROUND: Carrageenin (CAR) injection into the pleural cavity causes local inflammation called carrageenin-induced pleurisy (CAR-IP). Inflammation onset is characterized by an activation of pro-inflammatory NFKB, RelA-p50, while inflammation resolution is characterized by an activation of an antiinflammatory NFKB, p50-p50, that re-establishes homeostasis, an essential process for an organism's survival. Although chronic alcohol intake disrupts inflammation, the mechanism behind the development of inflammatory disorder in alcoholics is not yet known. Therefore, the aim of this investigation was to study the effects of ethanol intake on CAR-IP and NFKB activation in pleural fluid neutrophils in $P$ rats.

Methods: Alcohol-preferring, $P$ rats were given free choice of alcohol (15\% ethanol) and water or water alone (for control) for 15 days. Then, each rat was injected with $0.2 \mathrm{ml}$ of $2 \%$ CAR into the pleural cavity under light ether anesthesia. At different time intervals after the CAR injection, rats were anesthetized and their blood and pleural fluid samples were collected. Pleural fluid inflammatory cells were identified with Turk's or Wright-Giemsa staining. Different cell types were sorted using a fluorescenceactivated cell sorter. Pleural fluid neutrophils were examined for apoptosis and activation of the two NFкB subspecies.

Results: In control rats, fluid began to accumulate in the pleural cavity $0.5 \mathrm{~h}$ after, which peaked $24 \mathrm{~h}$ after, CAR injection. Then, the values declined gradually. The increase in pleural fluid correlated with RelA-p50 activation, while the decline in pleural fluid correlated with p50-p50 activation and apoptosis in neutrophils. In alcohol-drinking rats, pleural fluid remained elevated for up to 6 days after CAR injection. Neutrophils from alcohol-drinking rats exhibited suppressed apoptosis, augmented RelA-p50 activation, and suppressed p50-p50 activation.

Conclusions: Alcohol intake prolonged inflammation in $P$ rats. An alcohol-induced upregulation of RelAp50 activation and downregulation of p50-p50 activation may be causally related to the alcohol-induced inflammation dysregulation.

Key words: Alcohol, Carrageenin, NFkB, RelA-p50, p50p50, Apoptosis, Neutrophils

\section{Differential activation of NFkB/ RelA-p50 and NFkB/p50-p50 in control and alcohol-drinking rats subjected to carrageenin-induced pleurisy}

\author{
Ashok K. Singh ${ }^{\mathrm{CA}}$ and Yin Jiang
}

Department of Veterinary Population Medicine, College of Veterinary Medicine, University of Minnesota, St Paul Campus, St Paul, MN 55108, USA

\author{
${ }^{\mathrm{CA}}$ Corresponding Author \\ Tel: +16126256782 \\ Fax: +16126248707 \\ E-mail: singh001@umn.edu
}

\section{Introduction}

Carrageenin (CAR), when injected into the pleural cavity, causes tissue damage and local inflammation called carrageenin-induced pleurisy (CAR-IP). ${ }^{1}$ Plasma exudation is followed by neutrophil, monocyte and lymphocyte infiltration in the pleural cavity after CAR injection in rats., ${ }^{2,3}$ The exudate cells are programmed to undergo apoptosis that limits inflammatory response and re-establishes homeostasis., 4 $\mathrm{NF \kappa B}$, a family of dimeric transcription factors consisting of p50, p65 (Rel A), Rel B, c-Rel, p105 and p52/p100 monomers, plays a key role in both the evolution and resolution of inflammation. ${ }^{6,7}$ In resting cells $\mathrm{NF} \kappa \mathrm{B}$ exists as an inactive $\mathrm{NF \kappa B}$. I $\mathrm{B}$ complex, where I $\mathrm{KB}$ comprises $\mathrm{I} \kappa \mathrm{B} \alpha$, I $\mathrm{I} \mathrm{B} \beta$, $\mathrm{I} \kappa \mathrm{B} \gamma / \mathrm{p} 105$, I $\mathrm{I} \mathrm{B} \delta / \mathrm{p} 100$, or $\mathrm{I} \kappa \mathrm{B} \varepsilon{ }^{8}$ The first step in the activation process of $\mathrm{NF} \kappa \mathrm{B}$ is phosphorylation of

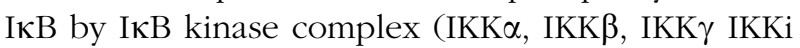
and $\mathrm{IKK \varepsilon}$ ) that phosphorylates $\mathrm{I} \kappa \mathrm{B}$ and releases active NFKB, which enters the nucleus and induces transcription of a number of genes. ${ }^{9-11}$ Phosphorylated $\mathrm{I} \kappa \mathrm{B} \alpha$ and its degradation by $26 \mathrm{~S}$ proteosome precedes NFKB nuclear translocation. ${ }^{12}$ Onset of inflammation is characterized by an activation of $\operatorname{IKK} \alpha / \operatorname{IKK} \beta$ and degradation of $\operatorname{I\kappa B} \alpha$, leading to 
activation of pro-inflammatory NFkB:RelA-p50. ${ }^{13}$ However, during resolution of inflammation, another $\mathrm{NF \kappa B}$ signaling pathway is involved that activates NFкB:p50-p50 homodimer, which induces transcription of anti-inflammatory genes. ${ }^{14,15}$ Since NFкB:p50p50 activation occurs when I $\mathrm{I} \mathrm{B} \alpha$ is present, it is proposed that $\operatorname{IKK} \alpha / \operatorname{IKK} \beta$ is not involved in this process. ${ }^{16}$ In the nucleus, NFKB:p50-p50 remains

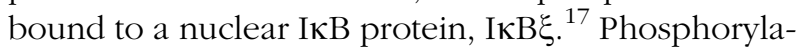
tion of $\mathrm{I} \kappa \mathrm{B} \xi$ activates $\mathrm{p} 50-\mathrm{p} 50$ that, by directly associating with transcriptional co-activators of the $\mathrm{C} / \mathrm{EBP}$ family or $\mathrm{Bcl} 2$, induces gene transcription and apoptosis, respectively. ${ }^{18,19}$ An interferon-inducible p202 family protein, p202a, suppresses the binding of DNA to RelA-p50, but augments the binding of DNA to $\mathrm{p} 50-\mathrm{p} 50$, leading to an increase in inflammation cell apoptosis. ${ }^{20}$

Establishment of homeostasis is essential for an organism's survival. A defect in the resolution of inflammation has been implicated in the development of many diseases including chronic cholecystitis, rheumatoid arthritis, Hashimoto's thyroiditis, inflammatory bowel disease (ulcerative colitis and Crohn's disease), cilicosis and other pneumoconiosis. ${ }^{21,22}$ Although chronic alcohol intake has also been shown to disrupt inflammation, immunity and liver function, ${ }^{23,24}$ the mechanism behind the development of inflammatory disorder in alcoholics is not yet known. A recent study has shown that Kupffer cells isolated from rats after chronic ethanol feeding exhibited upregulated lipopolysaccharide-induced tumor necrosis factor expression and extra-cellular receptor-activated kinases $1 / 2$ (ERK1/2) activity, but suppressed nuclear DNA binding of NFKB. ${ }^{25}$ Contrarily, other studies have shown that chronic ethanol increased NFKB activation, DNA binding of $\mathrm{NF \kappa B}$ in liver and other tissues, and susceptibility of rats to endotoxin-induced liver injury. ${ }^{22,26}$ Because of these conflicting observations regarding the effects of chronic alcohol intake on NFKB activation, further investigation examining $\mathrm{NF \kappa B}$ activation in ethanoldependent rats need to be carried out. We propose that chronic ethanol intake dysregulates CAR-IP by upregulating pro-inflammatory NFKB:RelA-p50 signaling, but suppressing the anti-inflammatory NFкB:p50-p50 signaling in rats. The chronic ethanol-induced dysregulation of inflammation may be critical for the progression of ethanol-induced peripheral toxicity such as liver damage, oxidative stress, and compromised immunity.

\section{Materials and methods}

\section{Animal handling}

Alcohol-preferring rats (180-200 g, University of Indiana, Bloomington, IN, USA) were kept in a control environment with light from 8:00 p.m. to 8 a.m. Food and water were given ad libitum. A group of rats were given free choice of ethanol (15\%) and pure water for 15 days as described previously. ${ }^{27,28}$ The other group received pure water. Then, pleurisy was induced by injecting each rat with $0.2 \mathrm{ml}$ of $2 \%$ CAR into the pleural cavity under light ether anesthesia. At different time intervals (1, 6 and $12 \mathrm{~h}$ and $1,2,3$, and 6 days; $n=4$ for each time interval, except $1 \mathrm{~h}$ and 2 day groups $n=12$ ) after CAR injection, rats were anesthetized with ether, blood samples were collected from the abdominal aorta, and the pleural cavity was opened. The cavity was rinsed with $1 \mathrm{ml}$ of phosphate-buffered saline and total fluids were collected in a tube containing $1 \mathrm{ml}$ of $77 \mathrm{mM}$ ethylenediamine tetraacetic acid (EDTA). For the $1 \mathrm{~h}$ and 2 day samples, pleural exudates from three rats were pooled for $n=4$.

\section{Pleural fluid}

The exudate volume was determined by subtracting the rinsing volume $(1 \mathrm{ml})$ from the total fluid volume. Then, for each time-line, pleural exudates from three rats were pooled to achieve $n=4$. A $100 \mu$ laliquot of pleural fluid was used for cell counting after staining with Turk's solution. For cell classification, a $200 \mu \mathrm{l}$ aliquot of pleural fluid was spun on a glass slide coated with poly-L-Lys (Sigma Chemicals Co., St Louis, MO, USA) by centrifugation for $5 \mathrm{~min}$. Then the slide was dried and fixed with 100\% methanol. Samples were stained with Wright-Giemsa solution and examined under a light microscope. Different cell types were sorted using a fluorescence-activated cell sorter and analyzed on a Becton Dickinson FACScalibur. The remaining pleural fluid was centrifuged at $800 \times g$ for $15 \mathrm{~min}$ and supernatant was collected in a test-tube and stored frozen for analysis of total $\mathrm{NO}_{2}$ and different cytokines. The pellets were subjected to neutrophil extraction as follows.

\section{Processing of exudate for neutrophil isolation}

The method described by Bustos et al. ${ }^{29}$ was modified for isolation of neutrophils from exudates. The anti-coagulated exudate was spun in a narrow test tube. The supernatant was carefully removed as much as possible without disturbing the interface coat. Buffered $2 \%$ glutaraldehyde was then very gently layered on top and the tube left to stand in the ice-bath for about a couple of hours. The interface layer was suspended in RPMI buffer that was layered onto Ficoll ( $25 \mathrm{ml}$ of buffer per $12.5 \mathrm{ml}$ of Ficoll) and centrifuged at $950 \times g$ for $7 \mathrm{~min}$. The Ficoll and supernatant interface was collected, mixed with $45 \mathrm{ml}$ of RPMI buffer and centrifuged at $350 \times \mathrm{g}$ for $7 \mathrm{~min}$. The cells suspension containing 150$200 \times 10^{6}$ cells were mixed with hyper-osmotic 
Percoll solution ( $48.5 \mathrm{ml}$ of Percoll in $45.5 \mathrm{ml}$ of water and $10 \mathrm{ml}$ of $1.6 \mathrm{M} \mathrm{NaCl}$ ) in a proportion of $3 \mathrm{ml}$ of cell suspension in $10 \mathrm{ml}$ of hyper-osmotic Percoll. The samples were centrifuged at $580 \times g$ for $15 \mathrm{~min}$. The cells at the interface were collected and suspended in RPMI buffer. The suspension was centrifuged at $350 \times g$ for $7 \mathrm{~min}$. The supernatant was discarded and the pellets were collected and overlayed onto isotonic Percoll solution $(3 \mathrm{ml}$ of cell suspension and $10 \mathrm{ml}$ of iso-osmotic Percoll). Cells were centrifuged at $350 \times g$ for $15 \mathrm{~min}$ and the supernatant discarded. The pellets containing neutrophils were suspended in RPMI to achieve approximately $150 \times 10^{6}$ cells $/ \mathrm{ml}$.

\section{Assessment of apoptosis in neutrophils}

Apoptosis in neutrophils was determined by double staining with annexin-V and propodium iodide. Cells were washed twice with cold phosphate-buffered saline and then resuspended in binding buffer (20 mM Hepes/NaOH, pH 7.4, $132 \mathrm{mM} \mathrm{NaCl}, 6 \mathrm{mM}$ $\mathrm{KCl}, 2.5 \mathrm{mM} \mathrm{CaCl}_{2}, 1 \mathrm{mM} \mathrm{MgSO} 4,1.2 \mathrm{mM} \mathrm{KH}_{2} \mathrm{PO}_{4}$, $5 \mathrm{mM}$ glucose, and $0.5 \%$ bovine serum albumin) at a concentration of $\sim 1 \times 10^{6}$ cells $/ \mathrm{ml}$. A $100 \mu \mathrm{l}$ sample of the solution $\left(\sim 1 \times 10^{5}\right.$ cells $)$ was transferred to a $5 \mathrm{ml}$ culture tube, and annexin-V $(25 \mathrm{ng} / \mathrm{ml})$ and propodium iodide $(10 \mathrm{ng} / \mathrm{ml})$ were added. Cells were mixed gently and incubated for $15 \mathrm{~min}$ at room temperature in the dark. Then $400 \mu$ l of binding buffer was added to each tube. The samples were analyzed within $1 \mathrm{~h}$, with $100 \mu \mathrm{l}$ of the sample viewed under the fluorescence microscope. Green annexin-V fluorescence indicated initiation of apoptosis and red propodium iodide fluorescence indicated late apoptosis.

\section{Preparation of nuclear extract ${ }^{30}$}

Neutrophils were suspended in ice-cold HEPES buffer consisting of $10 \mathrm{mM}$ HEPES, $1.5 \mathrm{mM} \mathrm{MgCl}_{2}$, $10 \mathrm{mM} \mathrm{KCl}, 0.5 \mathrm{mM}$ phenylmethylsulphonylfluoride, $1.5 \mu \mathrm{g} / \mathrm{ml}$ of soybean trypsin inhibitor, $7 \mu \mathrm{g} / \mathrm{ml}$ of pepstatin A, $5 \mu \mathrm{g} / \mathrm{ml}$ of leupeptin, $0.1 \mathrm{mM}$ of benzamidine and $0.5 \mathrm{mM}$ of dithiothreitol. The samples were homogenized briefly. The samples ( $2 \mathrm{ml}$ ) were mixed with $20 \mu \mathrm{l}$ of $10 \%$ Nonidet P-40 and centrifuged at $1500 \times g$ for $15 \mathrm{~min}$. The supernatant containing the cytosolic fraction was separated and stored at $-70^{\circ} \mathrm{C}$. The pellets were resuspended in $700 \mu$ of high-salt extraction buffer $(20 \mathrm{mM}$ HEPES, pH 9, $420 \mathrm{mM} \mathrm{NaCl}, 1.5 \mathrm{mM} \mathrm{MgCl}_{2}, 0.2 \mathrm{mM}$ EDTA, $25 \% \mathrm{v} / \mathrm{v}$ glycerol, phenylmethylsulphonylfluoride, $1.5 \mu \mathrm{g} / \mathrm{ml}$ of soybean trypsin inhibitor, $7 \mu \mathrm{g} / \mathrm{ml}$ of pepstatin A, $5 \mu \mathrm{g} / \mathrm{ml}$ of leupeptin, $0.1 \mathrm{mM}$ benzamidine and $0.5 \mathrm{mM}$ dithiothreitol) and incubated by shaking at $4^{\circ} \mathrm{C}$ for $30 \mathrm{~min}$. The nuclear extract was centrifuged at $13,000 \times g$ for $15 \mathrm{~min}$. The supernatant was collected and stored at $-70^{\circ} \mathrm{C}$ for further analysis.

\section{Electrophoretic mobility shift assay ${ }^{31}$}

Nuclear extracts from $1 \mathrm{~h}$ and $48 \mathrm{~h}$ rats were prepared as described previously. ${ }^{31}$ The electrophoretic mobility shift assay was performed using the $\left[{ }^{32} \mathrm{P}\right]$-labeled probes presented in Table 1.

For p202a super-shift assay, the nuclear mixture was incubated with p202a protein (Santa Cruz, Santa Cruz, CA, USA) at room temperature for $2 \mathrm{~h}$ and then incubated with p202a antibodies for another $12 \mathrm{~h}$ at $4^{\circ} \mathrm{C}$. Then the mixture was incubated with the labeled probes and electrophoresis was performed.

A double-stranded probe containing the NFкB recognition sequences was end-labeled with $\left[{ }^{32} \mathrm{P}\right]-$ adenosine triphosphate. The reaction mixture $(20 \mu \mathrm{l})$ included $200 \mathrm{ng}$ of nuclear extract protein, $40 \mathrm{fmol}$ of labeled probe $\left(5 \times 10^{4} \mathrm{cpm}\right), 10 \mathrm{mM}$ Hepes $(\mathrm{pH} 7.9)$, $10 \mathrm{mM} \mathrm{KCl}, 0.5 \mathrm{mM}$ dithiothreitol, $0.5 \mathrm{mM}$ EDTA, $0.2-1 \mu \mathrm{g}$ of poly(dI-dC), and $5 \%$ glycerol. After $2 \mathrm{~h}$ incubation at room temperature, the samples were loaded onto a $5 \%$ non-denaturing polyacrylamide gel electrophoreis gel at $200 \mathrm{~V}$ for $2 \mathrm{~h}$. The separated proteins were visualized by autoradiography. ${ }^{31}$ For super-shifts, the samples were incubated overnight at $4^{\circ} \mathrm{C}$ with specific antibodies against p65 (RelA) and p50 proteins prior to adding the probe.

A rationale for using multiple probes is as follows.

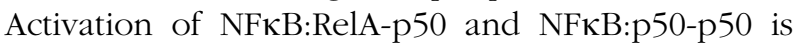
commonly studied by measuring binding of a double-stranded NFKB probe to the two proteins (electrophoretic mobility shift assay) and then causing super-shift with specific antibodies against the dimers. However, the disadvantage of using a single

Table 1. $\left[{ }^{32} \mathrm{P}\right]$-labeled probes used in the electrophoretic mobility shift assay

\begin{tabular}{|c|c|c|}
\hline RelA-p50 probe (P1) & $\begin{array}{l}\text { 5'-AGT TGA GGG GAC TTT CCC AGG CAA-3' } \\
3^{\prime} \text {-TCA ACT CCC CTG AAA GGG TCC GTT-5' }\end{array}$ & Reference 15 \\
\hline RelA-p50 probe (P2) & $\begin{array}{l}\text { 5'-GGT CCG TGA ATT CCC AGG GC-3' } \\
3^{\prime} \text {-CCA GGC ACT TAA GGG TCC CG-5' }\end{array}$ & Reference 15 \\
\hline RelA-p50/p50-p50 probe (P3) & $\begin{array}{l}5^{\prime} \text {-AAC AGG GGG CTT TCC TCC T-3' } \\
3^{\prime} \text {-TTC TCC CCC AAA GGG AGG A-5' }\end{array}$ & Reference 15 \\
\hline RelA-p50 probe (P4) & $\begin{array}{l}5^{\prime} \text {-GAT CCG GAG GAT TCC TTG ATG G-3' } \\
3^{\prime} \text {-CTA GGC CTC CTA AGG AAG TAC C-5' }\end{array}$ & Reference 32 \\
\hline p50-p50 probe (P5) & $\begin{array}{l}\text { 5'-TTA ACA AGG GGG CCT CCC CTC-3' } \\
3^{\prime} \text {-AAT TGT TCC CCC GGG GCC GAG-5' }\end{array}$ & Reference 33 \\
\hline
\end{tabular}


probe is that the probe may exhibit high-affinity binding to one protein and low-affinity binding to the other. This may yield erroneous results. The conventional NFKB probe containing a GGGACTTTCC motif exhibited high affinity for RelA-p50 but almost 15fold lower affinity for p50-p50. Earlier studies have shown that a probe containing the GGGGCCTCCC motif exhibited high affinity for NFKB:p50-p50. ${ }^{34}$ Also, Bohuslav et al..$^{15}$ designed probes that exhibited differential binding to the two proteins. In this study, we tested six probes for their differential binding to different NFKB proteins.

\section{Results}

\section{Pleural exudate and inflammation cells}

In control rats, the pleural exudate volume began to rise at $0.5 \mathrm{~h}$ after, and peaked at 2 days after, CAR injection. Then the volume declined gradually (Fig. 1). The pleural exudate volume reached a basal level 6 days after CAR injection. In alcohol-fed rats, the pleural exudate volume remained elevated for up to 6 days (Fig. 1). The exudate cells from basal control rats (no CAR) contained less than $10^{3} / \mu \mathrm{l}$ immune cells content. At $1 \mathrm{~h}$ after CAR injection, although the exudate volume did not change, the cell count increased to $10-50 \times 10^{6}$ cells $/ \mu$ l. Then exudate volume and cell count both increased and peaked at 2 days after CAR injection (600$800 \times 10^{6}$ cells $\left./ \mu \mathrm{l}\right)$. Neutrophils were the first to appear, followed by monocytes. The neutrophil count peaked at 2 days after CAR injection (Fig. 2). Then a gradual decrease was noted. There was a late increase in lymphocytes, occurring at 3 days after the

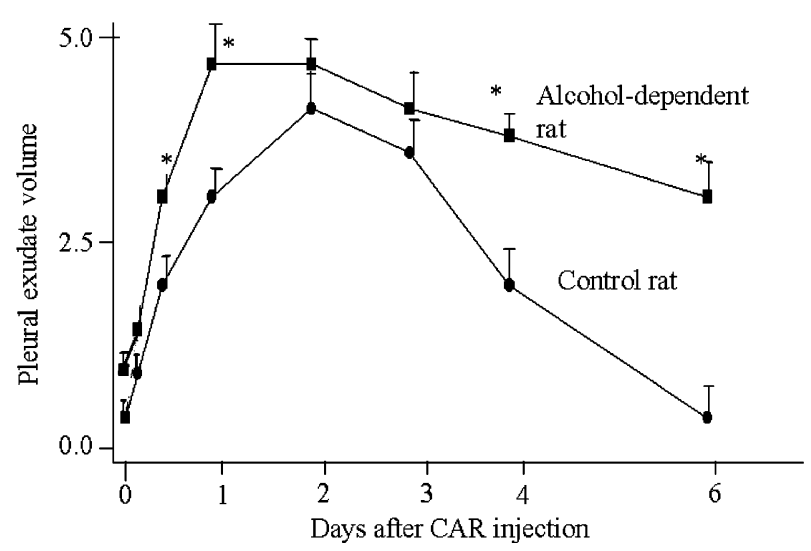

FIG. 1. Pleural exudate volume in water-drinking or alcoholdrinking $P$ rats subjected to CAR-IP. Values are mean \pm standard deviation, $n=4$. ${ }^{*}$ Significant $(P<0.05)$ when compared with corresponding control values.

injection. In alcohol-fed rats, the cell count remained elevated for up to 6 days.

Figure 3 shows the flow cytometric analysis of exduate cells. Control animals prior to CAR injection poorly contained the inflammatory cells (Fig. 3, basal). At day 2, the exudate cell count increased significantly. Neutrophil was the predominant cell group. At day 4, the cell count decreased but a new group of cells, possibly lymphocytes, appeared (Fig. 3, day 4). In exudate from alcohol-fed rats, the cell counts at day 4 were greater than the count in the day 2 samples (Fig. 3).

\section{Apoptosis}

In control rats, exudates cells collected 6 or $12 \mathrm{~h}$ after CAR injection poorly labeled with annexin- $\mathrm{V}$ or propodium iodide (Fig. 4 control). The annexin-V labeling increased thereafter. Propodium iodide
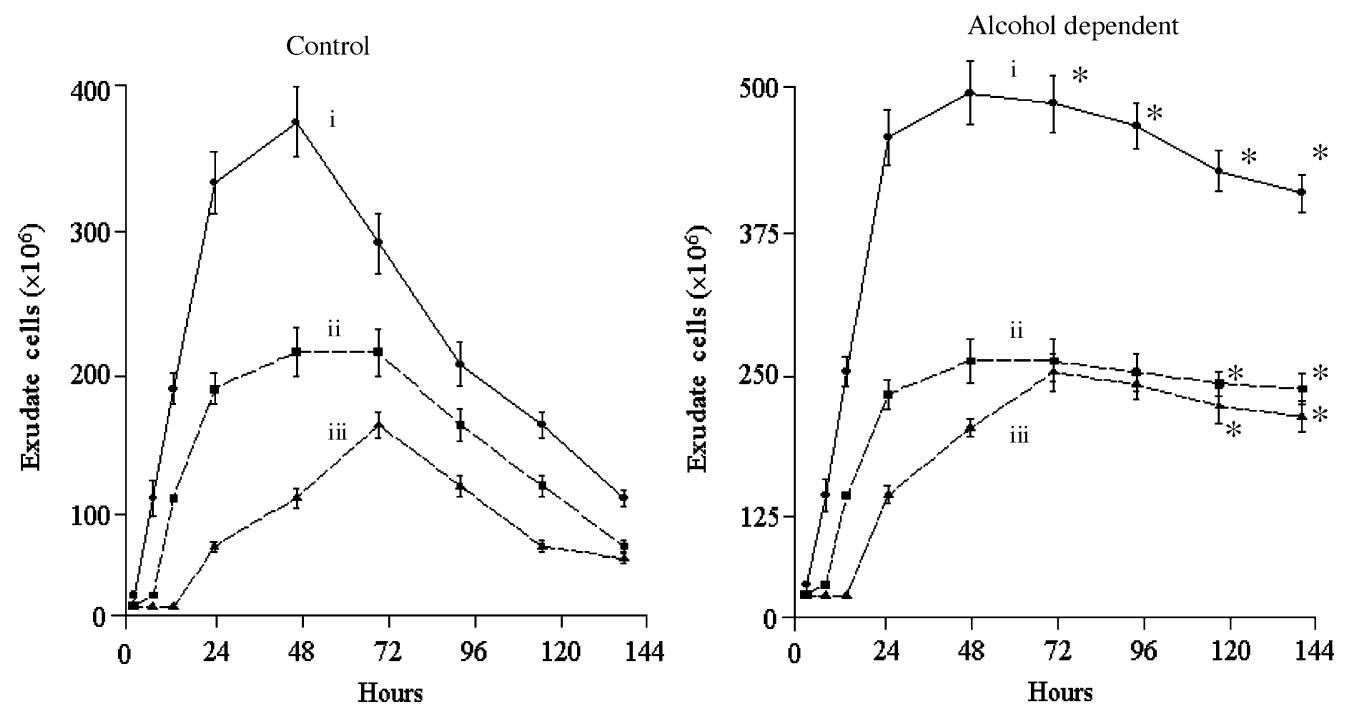

FIG. 2. Distribution of neutrophils (plot i), monocytes (plot ii) and lymphocytes (plot iii) in pleural exudates from waterdrinking or alcohol-drinking $P$ rats subjected to CAR-IP. Values are mean \pm standard deviation, $n=4$. ${ }^{*}$ Significant $(P<0.05)$ when compared with corresponding control values. 

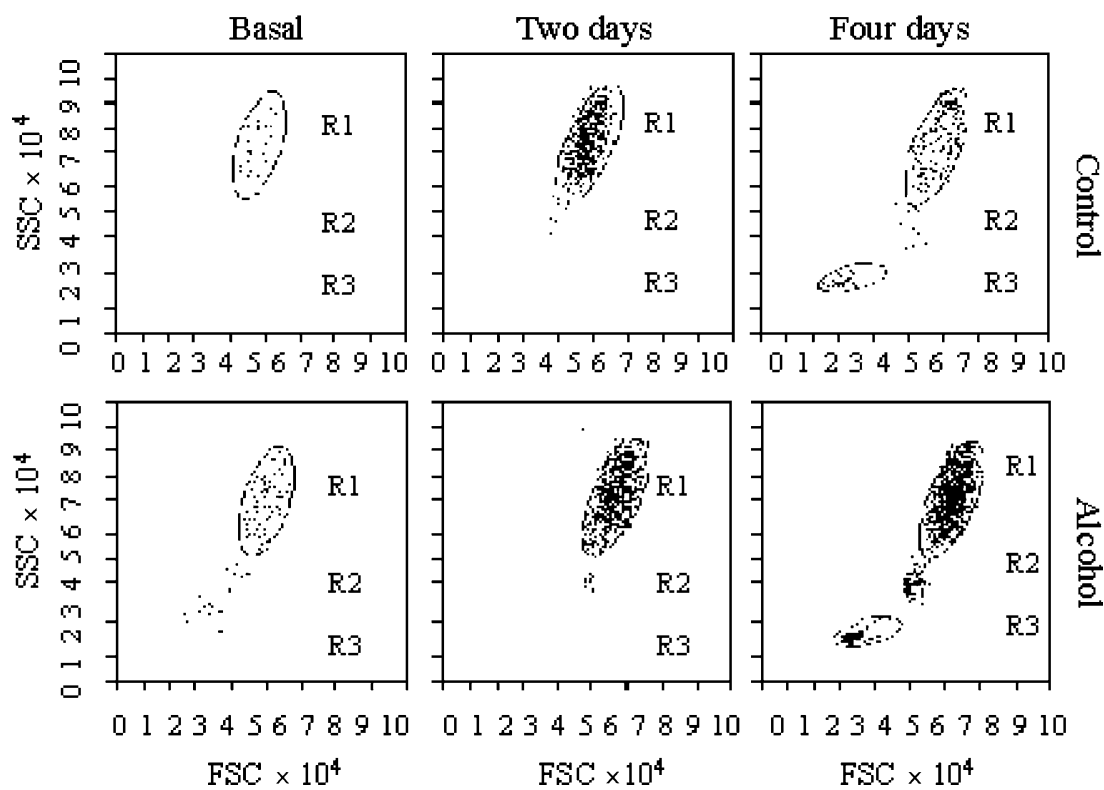

FIG. 3. Flow-cytometric analysis of different cells in pleural exudates from water-drinking or alcohol-drinking P-rats. R1, neutrophils; R2, monocytes; R3, lymphocytes. SSC: Side Scatter Coordinates. FSC: Forward Scatter Coordinates.

staining appeared at 4 days after CAR injection. Propodium iodide staining was abundant at 4 and 6 days after CAR injection. Apoptosis was delayed in alcohol-fed rats (Fig. 4 alcohol). A suppression of apoptosis in alcohol-fed rats may account for the persistence of inflammation cells in the exudate.

\section{Electrophoretic mobility shift assay (Fig. 5)}

Control rats. At $1 \mathrm{~h}$ after CAR injection, the mobility shift assay showed that probes $\mathrm{P} 1-\mathrm{P} 4$ yielded a band at $80 \mathrm{kDa}$ that corresponded to the RelA-p50-probe complex and probe $\mathrm{P} 5$ did not bind to any protein. Thus, the probe P5 binding protein was not expressed at $1 \mathrm{~h}$ after CAR injection. At 2 days after CAR injection, $\mathrm{P} 1, \mathrm{P} 2$, and $\mathrm{P} 4$ yielded the $80 \mathrm{kDa}$ band that corresponded to the RelA-p50-probe complex, while P3 also yielded a $60 \mathrm{kDa}$ band that corresponded to the $\mathrm{p} 50-\mathrm{p} 50-$ probe complex. $\mathrm{P} 5$ yielded only one band that corresponded to the p50-p50probe complex. This showed that the probes $\mathrm{P} 1$ or $\mathrm{P} 2$ selectively bound RelA-p50, P6 selectively bound p50-p50, and P3 bound to both complexes. This was further confirmed by studying the p202a supershift assay. Only P3 and P5 probes interacted with p202a, which has been shown to specifically bind $\mathrm{p} 50-\mathrm{p} 50$. The radioactivity incorporation in RelA-p50 band increased $0.5 \mathrm{~h}$ after CAR injection and then declined gradually (Fig. 6). The radioactivity incorporation in the p50-p50 band increased at $12 \mathrm{~h}$ after, and peaked at $24 \mathrm{~h}$ after, CAR injection (Fig. 6).

Alcobol-drinking rats. Binding of probes to RelAp50 in samples from control and alcohol-fed rats was comparable. However, alcohol-fed rats lacked the p50-p50 band (Fig. 5). Thus alcohol suppresses induction of the anti-inflammatory NFKB, p50-p50. The radioactivity incorporation in the RelA-p50 band increased $0.5 \mathrm{~h}$ after CAR injection and then declined gradually (Fig. 6). The values were greater than the control values. The radioactivity incorporation in the p50-p50 band increased poorly at $24 \mathrm{~h}$ after injection (Fig. 6). Radioactivity levels in p50-p50 bands from

\section{Control-CAR}

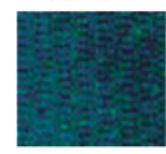

0

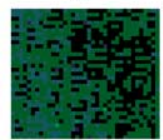

Alcohol-CAR

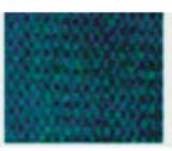

6

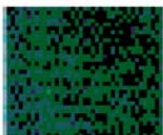

24

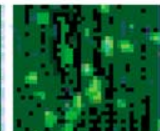

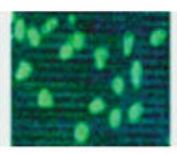

48

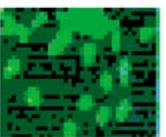

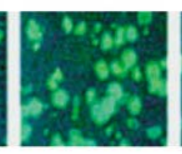

72

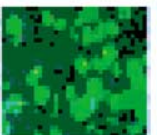

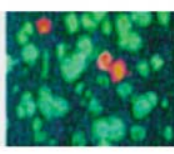

96

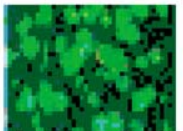

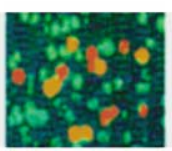

120

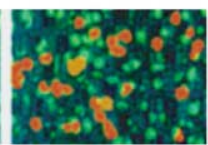

144 Hours
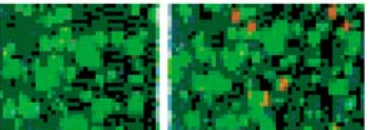

FIG. 4. Apoptosis in exudate neutrophils from water-drinking or alcohol-drinking $P$ rats subjected to CAR-IP. Green fluorescence is from annexin- $\mathrm{V}$ and red fluorescence is from propodium iodide. 

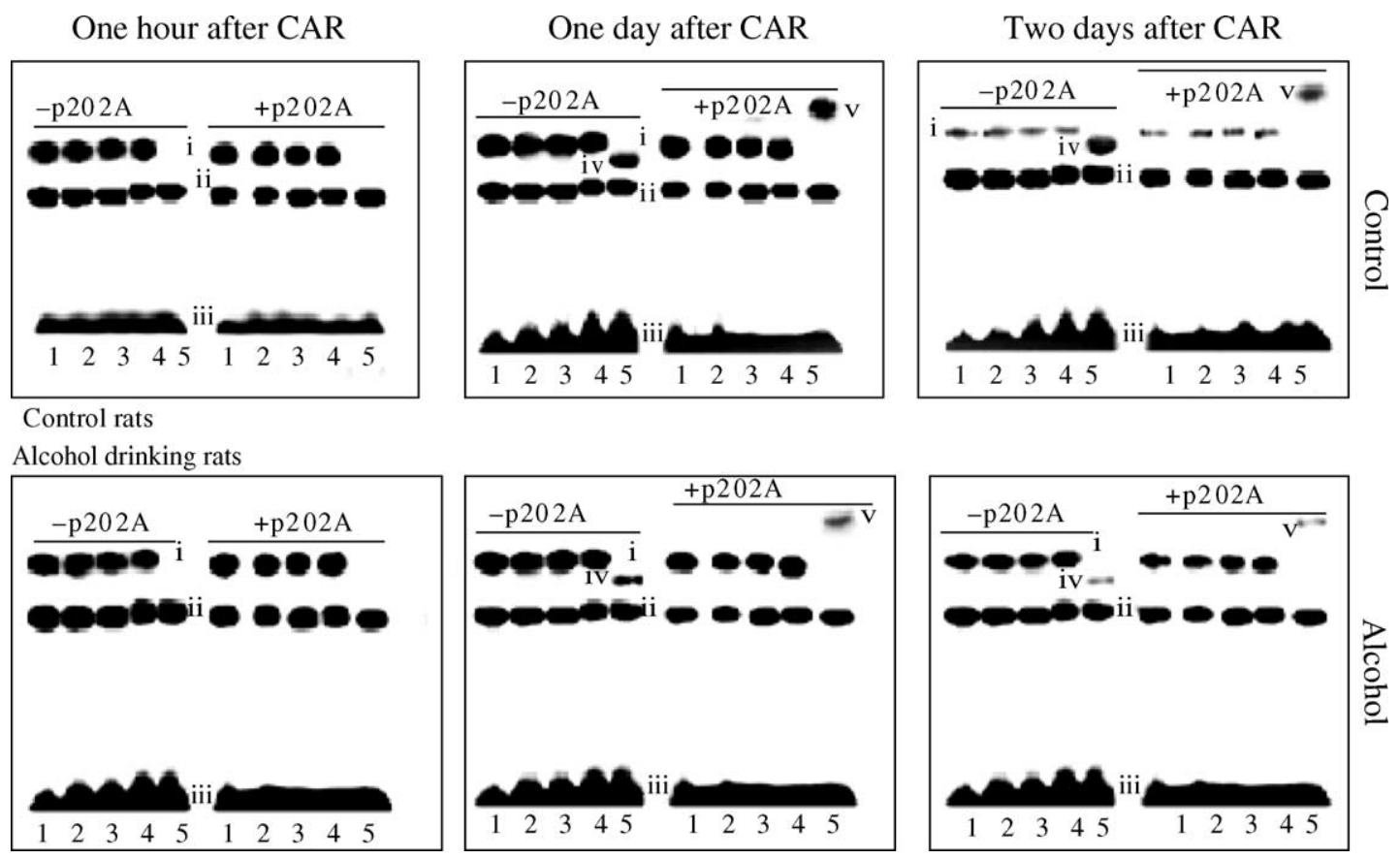

FIG. 5. Binding of different oligonucleotide probes to exudate neutrophil nuclear proteins form water-drinking or alcoholdrinking P rats subjected to CAR-IP. Lanes 1-5 represent probes 1-5, respectively. i: ReIA-p50 band; ii: unidentified band; iii: free probe; iv: p50-p50 band; v: p50-p50:p202a supershift.

alcohol-fed rats were several fold lower than that in control rats.

\section{Discussion}

This study showed that plasma fluid began to accumulate into the pleural cavity $0.5 \mathrm{~h}$ after CAR injection. The fluid level peaked 2 days and returned to the basal level 5-6 days after CAR injection in control rats. Neutrophils were detected first, followed by monocytes and lymphocytes in the pleural fluid. The time-course of accumulation of cells in the pleural exudate corresponded to that of fluid accumulation into the pleural cavity. Apoptotic cells were not detected during the first $12 \mathrm{~h}$, but began to appear thereafter. In alcohol-drinking rats, however, considerable fluid accumulation and neutrophils were noted 6 days after CAR injection. Apoptosis was significantly suppressed in alcohol-drinking rats subjected to CARIP. Thus, alcohol augmented the CAR-induced inflammation but suppressed its resolution in rats.

An activation of the pro-inflammatory NFKB, RelAp50, was observed in exudate neutrophils collected from control rats at $0.5 \mathrm{~h}$ after CAR injection. Activation peaked at $1 \mathrm{~h}$ after CAR injection. RelA-p50 activation has been shown to induce the transcription

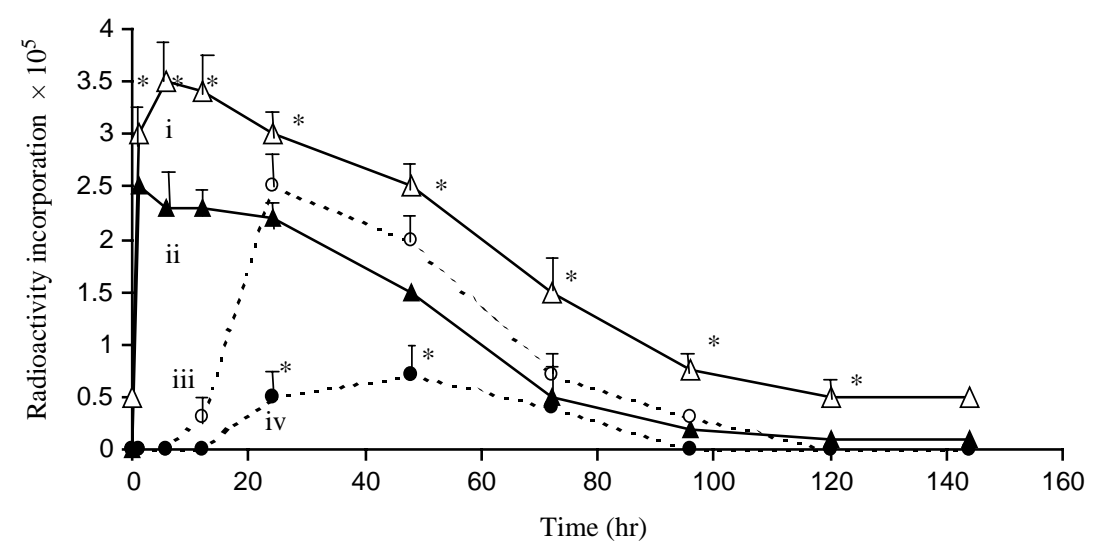

FIG. 6. Radioactivity incorporation in different bands representing RelA-p50 (triangles) or p50-p50 (circles). Open triangles or circles represent control rats and solid triangles or circles represent alcohol-drinking rats. Values are mean \pm standard deviation, $n=4$. * Significant $(P<0.05)$ when compared with corresponding control values. Radioactivity incorporation in RelA-p50 band from control (i) and alcohol-drinking (ii) rats, and in p50-p50 band from control (iii) and alcohol-drinking (iv) rats. 
of pro-inflammatory genes including tumor necrosis factor, interferon, interleukin-1 and interleukin-10 genes. ${ }^{6}$ However, $12 \mathrm{~h}$ after CAR injection in control rats, activation of an anti-inflammatory NFKB, p50p50, occurred that peaked $24 \mathrm{~h}$ after CAR injection.

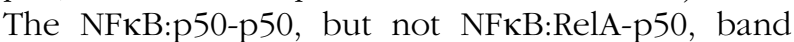
exhibited a super-shift in the presence of p202A. NFKB:p50-p50 has been shown to resolve inflammation by inducing transcription of anti-inflammatory and pro-apoptotic genes and suppressing transcription of pro-inflammatory genes. ${ }^{35}$ Similar to this study, earlier studies have also shown that CAR injection activated NFKB:RelA-p50 during initiation of inflammation. ${ }^{16,36}$ Thus, a suppression in pro-inflammatory NFкB:RelA-p50 activation will suppress inflammation, while a suppression in anti-inflammatory NFкB:p50p50 activation will delay or prevent resolution of inflammation, causing chronic inflammatory diseases.

This study also showed that RelA-p50 activation was augmented, while p50-p50 activation was suppressed in exudate neutrophils from alcohol-drinking rats subjected to CAR injection. Earlier studies have associated p50-p50 activation with resolution of inflammation. ${ }^{16,37}$ Since activation of p50-p50 also induces of apoptosis possibly through bcl-2, ${ }^{18,19}$ we propose that the suppressive effects of alcohol on p50-p50 activation may be responsible for dysregulation of CAR-IP. As discussed earlier, appropriate activation of RelA-p50 and p50-p50 is essential for optimal inflammatory response following injury or bacterial infection. An impaired p50-p50 activation has been shown to be associated with dysregulated inflammation, ${ }^{22,24,38-40}$ liver function, ${ }^{41-43}$ and cancer growth. ${ }^{4,45}$ since alcoholism has also been associated with dysregulated inflammation, ${ }^{46}$ hepatitis, ${ }^{47,48}$ and an increased cancer incidence, ${ }^{49,50}$ it is possible that an alcohol-induced impairment in RelAp50 and p50-p50 activation may be causally related to its peripheral toxicity.

\section{References}

1. Vinegar H, Truax JF, Selph JI. Some quantitative temporal characteristics of carrageenin-induced pleurisy in rats. Proc Soc Exp Biol Med 1973 143: $711-714$

2. De Rosa M. Biological properties of carrageenan. J Pharm Pharmacol 1972; 24: 89-102.

3. Murai N, Nagai K, Fujisawa H, Hatanaka K, Kawamura M, Harada Y. Concurrent evolution and resolution in an acute inflammatory model of rat carrageenin-induced pleurisy. J Leuko Biol 2003; 73: 456-463.

4. Grigg JM, Savill JS, Sarraf C, Haslett C, Silverman M. Neutrophil apoptosis and clearance from lungs. Lancet 1991; 338: 720-722.

5. Hussain N, Wu F, Zhu L, Thrall RS, Kresch MJ. Neutrophil apoptosis during the development and resolution of oleic acid induced acute lung injury in rat. Am J Resp Cell Mol Biol 1998; 19: 867-874.

6. Ghosh S, Karin M. Missing pieces in the NFKB puzzle. Cell 2002; 109(Suppl): $S 81-S 96$.

7. Li Q, Verma IM. NFKB regulation in the immune system. Nat Rev Immunol 2002; 2: 725-734.

8. De Bosscher K, Berghe WV, Haegeman G. The interplay between the glucocorticoid receptor and nuclear factor- $\mathrm{\kappa B}$ or activator protein-1: molecular mechanisms of gene repression. Endocr Rev 2003; 24: 488622

9. Israel A. The IKK complex: an integrator of all signals that activate NFKB? Trends Cell Biol 2001; 10: 129-133.
10. Kravchenko VV, Mathison JC, Schwamborn K, Mercuroi F, Ulevitch RJ. $\mathrm{IKKi} / \mathrm{IKK} \varepsilon$ plays a key role in integrating signals induced by proinflammatory stimuli. J Biol Chem 2003; 278: 26612-26619.

11. Sizemore N, Lerner N, Dombrowski N, Sakurai H, Stark GR. Distinct

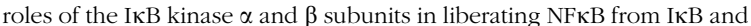
in phosphorylating the p65 subunit of NFKB. J Biol Chem 2002; 277: 3863-3869

12. Karin M, Ben-Nariah Y. Phosphorylation meets ubiquitination: the control of NFкB activity. Ann Rev Immunol 2000; 18: 621-663.

13. Tak PP, Firestein GS. NFאB: a key role in inflammatory diseases. J Clin Invest 2001; 107: 7-11.

14. Campbell IK, Gerondakis S, O'Donnell K, Wicks IP. Distinct roles for the $\mathrm{NF \kappa B}$ and c-Rel transcription factors in inflammatory arthritis. $J$ Clin Invest 2000; 105: 799-1806.

15. Bohuslav J, Kravchenko VV, Parry GCN, Erlich JH, Gerondakls S, Mackman N. Regulation of an essential innate immune response by the p50 subunit of $\mathrm{NF \kappa B}$. J Clin Invest 1998; 102: 1645-1652.

16. Lawrence T, Gilroy DW, Colville-Nash PR, Willoughby DA. Possible new role for NFKB in the resolution of inflammation. Nat Med 2001; 7: 12911297

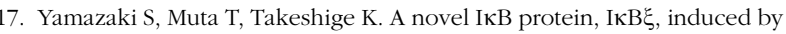
pro-inflammatory stimuli, negatively regulates nuclear factor- $\mathrm{\kappa B}$ in the nuclei. I Biol Chem 2001; 276: 27657-27662.

18. Kurland JF, Kodym R, Story MD, Spurgers KB, McDonnell TJ, Meyn RE. NFKB1 (p50) homodimers contribute to transcription of bcl-2 oncogens. I Biol Chem 2001; 276: 45380-45386.

19. Kurland JF, Voehringer DW, Meyn E. The MEK/ERK pathway acts upstream of NFKB1 (p50) homodimer activity and Bcl-2 expression in a murine B-cell lymphoma cell line. MEK inhibition restores radiationinduced apoptosis. J Biol Chem 2003; 278: 32465-32470.

20. Ma X-Y, Wang H, Ding B, Zhong H, Ghosh S. The interferon-inducible p202a protein modulates NFKB activity by inhibiting the binding to DNA of p50/p65 heterodimer and p65 homodimer while enhancing the binding of p50 homodimer. J Biol Chem 2003; 278: 23008-23019.

21. Jokelainen $\mathrm{K}$, Reinke LA, Nanii AA. NFKB activation is associated with free radical generation and endotoxemia and precedes pathological liver injury in experimental alcoholic liver disease. Cytokine 2001; 16: 36-39.

22. Szabo G, Mandrekar P. Ethanol-mediated deregulation of transcription factors in immunocompetent cells. Front Biosci 2002; 7: a80-a89.

23. Nanji AA, Zakim D. Alcoholic liver disease. In: Zakim D, Boyer TD, eds. A Textbook of Liver Disease, Philadelphia: Saunders, 1996: 891-961.

24. Szabo G. Consequences of alcohol consumption on host defense. Alcobol Alcohol 1999; 43: 830-841.

25. Kishore R, Hill JR, McMullen MR, Frenkel J, Nagy LE. ERK1/2 and Egr-1 contribute to increased TNF- $\alpha$ production in rat Kupffer cells after chronic ethanol feeding. Am J Physiol Gastroint Liver Physiol 2002; 282: G6-G15.

26. Uesegi T, Froh M, Arteel GE, Bradford BU, Gabele E, Wheeler MD, Thurman RG. Delivery of IאB superrepressor gene with adenovirus reduces early alcohol-induced liver injury in rats. Hepatology 2001; 34: $1149-1157$.

27. Benlhabib E, Baker JI, Keyler DE, Singh AK. Kudzu root extract suppresses voluntary intake and alcohol withdrawal symptoms in $\mathrm{P}$ rats receiving free access to water and alcohol. J Med Food 2004; 7: $168-179$.

28. Benlhabib E, Baker JI, Keyler DE, Singh AK. Effects of purified puerarin on voluntary alcohol intake and alcohol withdrawal symptoms in P rats receiving free access to water and alcohol. J Med Food 2004; 7: 180-186.

29. Bustos G, Ferrandiz MC, Sanz MJ, Paya M, Alcaraz MJ. A study of the novel anti-inflammatory agent florifenine. Topical anti-inflammatory activity and influence on arachidonic acid metabolism and neutrophil functions. Nauchn Sch Arch Pharmacol 2000; 10: 285-288.

30. Andrews NC, Faller DV. A rapid micropreparation technique for extraction of DNA binding proteins from limiting numbers of mammalian cells. Nucl Acid Res 1991; 19: 2499.

31. Singh AK. Effects of acephate and methamidophos on corticotrophin releasing-factor (CRF) synthesis in and corticosterone release from the hypothalamus in vitro. Comp Biochem Physiol 2002; 132: 9-24.

32. Baer M, Dillner A, Schwartz RC, Sedon C, Nedospasov S, Johnson PF. Tumor necrosis factor $\alpha$ transcription in macrophages is attenuated by an autocrine factor that preferentially induces NF- $\mathrm{\kappa B}$ p 50 . Mol Cell Biol 1998; 18: $5678-5689$

33. Knuefermann P, Chen P, Misra A, Shi SP, Abdellatif M, Sivasubramanian $\mathrm{N}$. Myotrophin/ $\mathrm{V}-1$, a protein up-regulated in the failing human heart and in postnatal cerebellum, converts NFkappa B p50-p65 heterodimers to p50-p50 and p65-p65 homodimers. J Biol Chem 2002; 277: $23888-$ 23897

34. Pan J, McEver RP. Regulation of the human P-selectin promoter by $\mathrm{Bcl}-3$ and specific homodimeric members of the NF-kappa B/Rel family. J Biol Chem 1995; 270: 23077-23083.

35. Akgul C, Moulding DA, Edwards SW. Molecular control of neutrophil apoptosis. FEBS Lett 2001; 487: 318-322.

36. D'Acquisto F, Ialenti A, Ianaro A, Carnuccio R. Nuclear factor- $\kappa B$ activation mediates inducible nitric oxide synthase expression in carrageenin-induced rat plurisy. Arch Pharmacol 1999; 360: 670-675. 
37. Laight DW, Lad N, Woodward B, Waterfall JF. Assessment of myeloperoxidase activity in renal tissue after ischemia/reperfusion. Eur $J$ Pharmacol 1995; 292: 81-88.

38. Chao YC, Wang SJ, Chu HC, Chang WK, Hsieh TY. Investigation of alcohol metabolizing enzyme genes in Chinese alcoholics with avascular necrosis of hip joint, pancreatitis and cirrhosis of the liver. Alcobol Alcobol 2003; 38: $431-436$

39. Chen J, Raj N, Kim P, Andrejko KM, Deutschman CS. Intrahepatic nuclear factor-kappa B activity and alpha 1-acid glycoprotein transcription do not predict outcome after cecal ligation and puncture in the rat. Crit Care Med 2001; 29: 589-596.

40. Mou SS, Haudek SB, Lequier L, Pena O, Leonard S, Nikaidoh H, Giroir BP, Stromberg D. Myocardial inflammatory activation in children with congenital heart disease. Crit Care Med 2002; 30: 827-832.

41. Vasiliou V, Lee J, Pappa A, Petersen DR. Involvement of p65 in the regulation of NF-kappaB in rat hepatic stellate cells during cirrhosis. Biochem Biophys Res Commun 2000; 273: 546-550.

42. Tacchini L, Dansi P, Matteucci E, Desiderio MA. Hepatocyte growth factor signal coupling to various transcription factors depends on triggering of Met receptor and protein kinase transducers in human hepatoma cell HepG2. Exp Cell Res 2000; 256: 272-281.

43. Carey EJ, Balan V, Kremers WK, Hay JE. Osteopenia and osteoporosis in patients with end-stage liver disease caused by hepatitis $\mathrm{C}$ and alcoholic liver disease: not just a cholestatic problem. Liver Transplant 2003; 9 $1166-1173$.
44. Thornburg NJ, Pathmanathan R, Raab-Traub N. Activation of nuclear factor-kappaB p50 homodimer/Bcl-3 complexes in nasopharyngeal carcinoma. Cancer Res 2003; 63: 8293-8301.

45. Dong QG, Sclabas GM, Fujioka S, et al. The function of multiple IkappaB:NF-kappaB complexes in the resistance of cancer cells to Taxol-induced apoptosis. Oncogene 2002; 21: 6510-6519.

46. Imhof A, Koenig W. Alcohol inflammation and coronary heart disease. Addiction Biol 2002; 8: 271-277.

47. Keshavarzian A, Fields J. Alcoholic liver disease: is it an 'extraintestinal' complication of alcohol-induced intestinal injury? J Lab Clin Med 2003; 142: $285-287$.

48. Barrio E, Tome S, Rodriguez I, Gude F, Sanchez-Leira J, Perez-Becerra E, Gonzalez-Quintela A. Liver disease in heavy drinkers with and without alcohol withdrawal syndrome. Alcohol Clin Exp Res 2004; 28: 131-136.

49. Horie Y, Yamagishi Y, Kajihara M, Kato S, Ishii H. National survey of hepatocellular carcinoma in heavy drinkers in Japan. Alcohol Clin Exp Res 2003; 27(8 Suppl): $32 \mathrm{~S}-36 \mathrm{~S}$.

50. Seitz HK, Stickel F, Homann N. Pathogenetic mechanisms of upper aerodigestive tract cancer in alcoholics. Int J Cancer 2004; 108: 483487.

Received 22 April 2004

Accepted 2 June 2004 


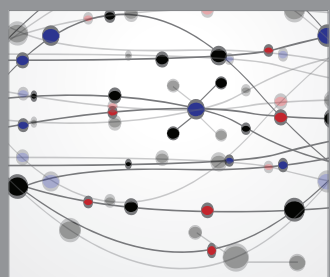

The Scientific World Journal
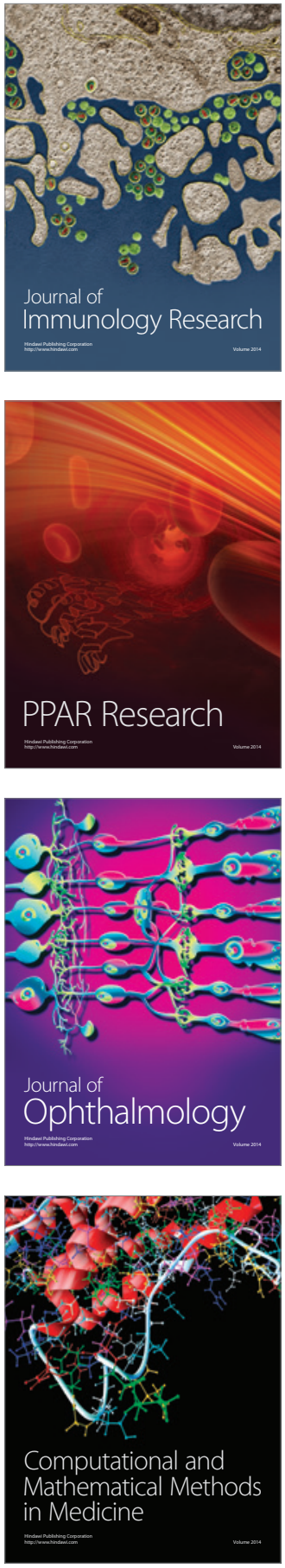

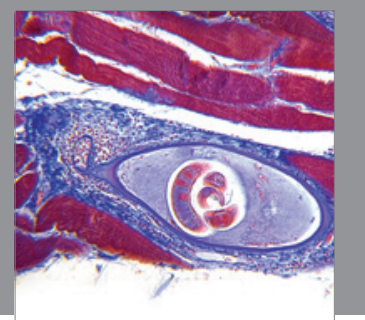

Gastroenterology

Research and Practice
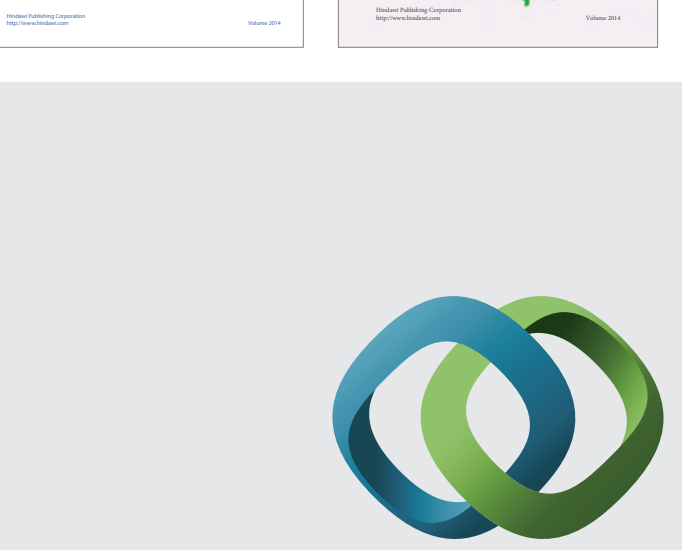

\section{Hindawi}

Submit your manuscripts at

http://www.hindawi.com
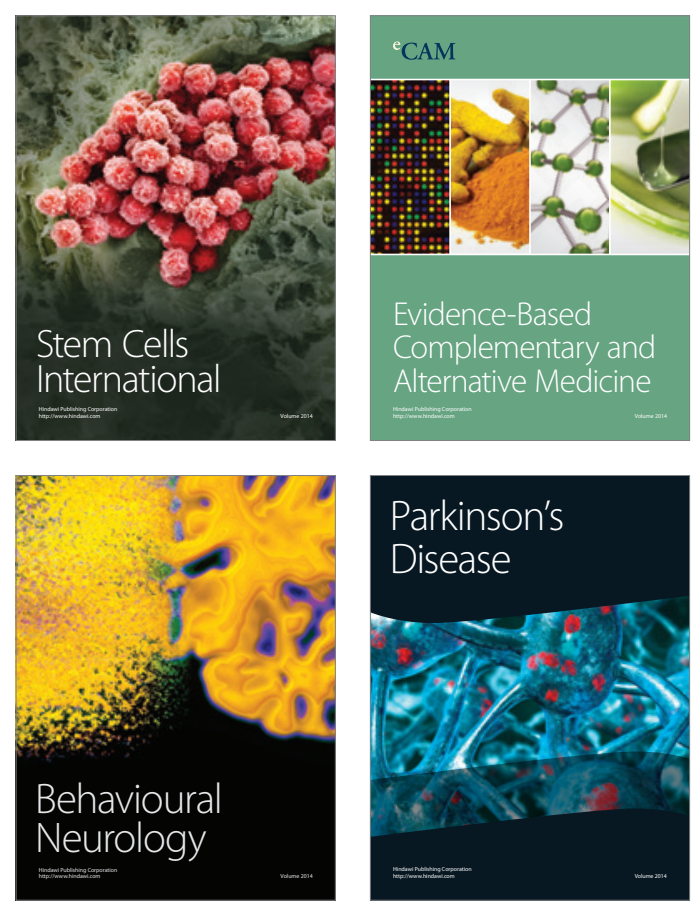

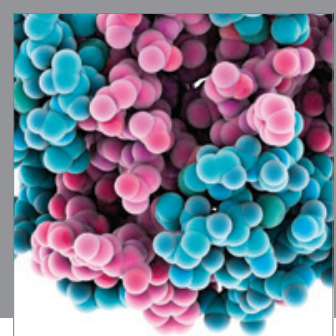

Journal of
Diabetes Research

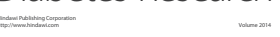

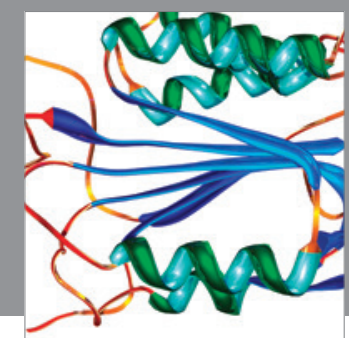

Disease Markers
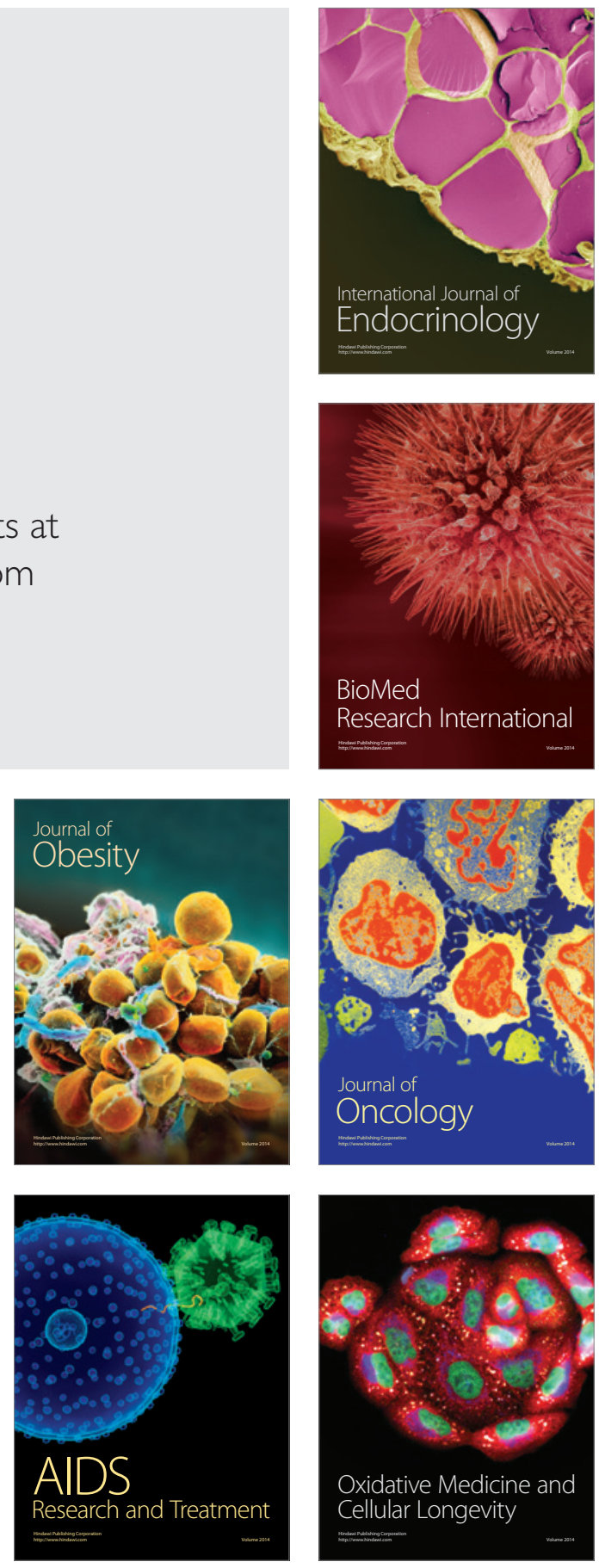